Journal of Architectural Research and Education (JARE)

Vol. 1 (2) 176-186

@। Nyoman Gede Maha Putra. 2019

DOI: 10.17509 /jare.v1i2.22309

\title{
Exploring the Architecture of Bali Post Hasta Kosala Kosali
}

\section{Nyoman Gede Maha Putra ${ }^{1}$}

${ }^{1}$ Department of Architecture, Faculty of Engineering and Planning, Universitas Warmadewa, Denpasar - Bali, Indonesia

1 Jalan Terompong No. 24 Tanjung Bungkak, Denpasar-Bali, Indonesia

Corresponding Author: gedemahaputra@gmail.com

Received: 5 Oktober 2019
Revised: 15 November 2019
Article History:

Accepted: 20 Desember Available online: 31 Desember 2019

\begin{abstract}
As the product of culture and the background of human activities, architecture and its identity are in a state of constant modification. This paper explores the development and change of architecture identity of a vernacular landscape after external power of colonialization introduces new technique and construction method and trends replacing the more traditional know how. A case study in Bali, an island famous for its tourist attractions, is analyzed through historical research involving document and policy analysis, in depth interview with key informants and observation and building surveys. The island is famous because of its cultural identity but nowadays experiencing rapid changes. Prior to colonization era, the island was developed based on local building codes called Hasta Kosala-Kosali that is written on traditional lontar leaf manuscripts. The result shows that new political system as well as business interests are two main factors influencing the transformation of architectural identity of the island in the post-colonial era to date. In order to maintain the attractiveness of the island, the public and private sector should work together with the community in establishing policies regarding the physical development of Bali.
\end{abstract}

Keywords: Architectural identity, tradition, post-colonialism, hasta kosala-kosali

\section{Introduction}

Place -Identity has become the axis of architectural debate in Bali lately. We often hear criticism about identity-oriented development which is feared to erode the culture of local architecture. Something that actually has emerged since more than 100 years ago since professional architects began to open the practice of architecture in the area we now know as the Republic of Indonesia. The roles of architects and non-traditional government administrators can unconsciously encourage transformation that undermines the traditional roles managed by the customary government system in shaping identity.

Place-identity is formed by, for example, human perception. Perception of one or a group of people can be different from humans or other groups. This difference in perception is influenced by many things such as cultural background, experience, level of education, age and even gender. In addition to different groups, perceptions can also change over time so that the same person or group of people can have different perceptions of an object at different times. Inequality of perception in seeing identity among space-creating actors: policy controllers, architects, investors triggers discourse. On the other hand the community as users of space feel they do not have enough power to be involved in the process of space transformation.

Today, architecture in the region known as Indonesia is syncretism from traditional architectural cultures, colonial architecture, nationalism expressions and also the insistence of modern currents that accompany investment. Most areas in the west of the country experienced acculturation with architecture from India, Arabia and subsequently experienced European colonialism. In the East, parts of the region were once under the influence of the Portuguese, Spanish and Dutch. The history of trade and the conquest of these areas gives color to the local architecture. Transfers of investment and capital that occur without boundaries today also affect identity transformation. What about the tradition of Balinese architecture as the last island subdued by Europeans and now one of the international investment destinations? Are there effects from 
encounters with Europeans on architecture? How did the nationalism movement in the early 1950s of Indonesia influence traditional architecture? Does the wave of tourism help to preserve or actually weaken the Balinese architectural identity? Can traditions and loyalty to the character of this island be maintained? This paper tries to provide insight to uncover a little mystery of the transformation of architectural identity in this earthquake and volcano-rich region.

Limited resources and information are the main shortcomings of this kind of search. However, it is endeavored wherever possible that the sources used are valid. Besides that, what needs to be put forward in this kind of writing is the framework that is built. Data that has not yet been collected can be entered and validated later into this framework. In addition, it is not easy to break down a hundred years long history into a concise article. For this reason, all shortcomings belong to the author.

\section{Theoritical Review}

\subsection{Traditions of Balinese Architecture and place-identity in the Pre-Colonial Period}

Traditional Balinese people see themselves as an inseparable part of the place where they live. They believe in living in harmony with the workings of the universe. Natural elements are always taken into account in the efforts of the community to organize, set goals and give meaning to the life they lead. Mountains and oceans, the movement of the sun, moon and star composition, direction of the wind, river flow and other elements are constructed in such a way as to become symbols of the cosmos. Mysteries regarding birth, death, and soul journey also form the core of the traditional belief systems of traditional societies. Traditional knowledge gained from observation and understanding of nature and how it works is referred to as cosmology.

The cosmological construction of Balinese traditional society is formed by the mountain-sea axis and the setting sun. In addition, the world is also believed to be composed of three layers: top, middle and bottom. From this understanding, buildings that are considered important are placed in higher areas and in the direction of the rising sun. Buildings with low values are placed in the opposite direction, while residential buildings are in between. Without realizing it, an understanding of the importance of maintaining the mountain area as a store and provider of water for agriculture and awareness of the possibility of the eruption of the mountain.

The building construction system is made with a frame structure with the material used arranged according to its position. Stones and clay are placed at the bottom or feet while wood and bamboo are used as construction materials for space or building bodies. The roof makes use of leaf material, both reeds and coconut leaves. Material should not be reversed: the lower part of the wooden or bamboo culm should not be placed on top. Practically, this kind of construction knowledge makes the building stable over the earthquake zone.

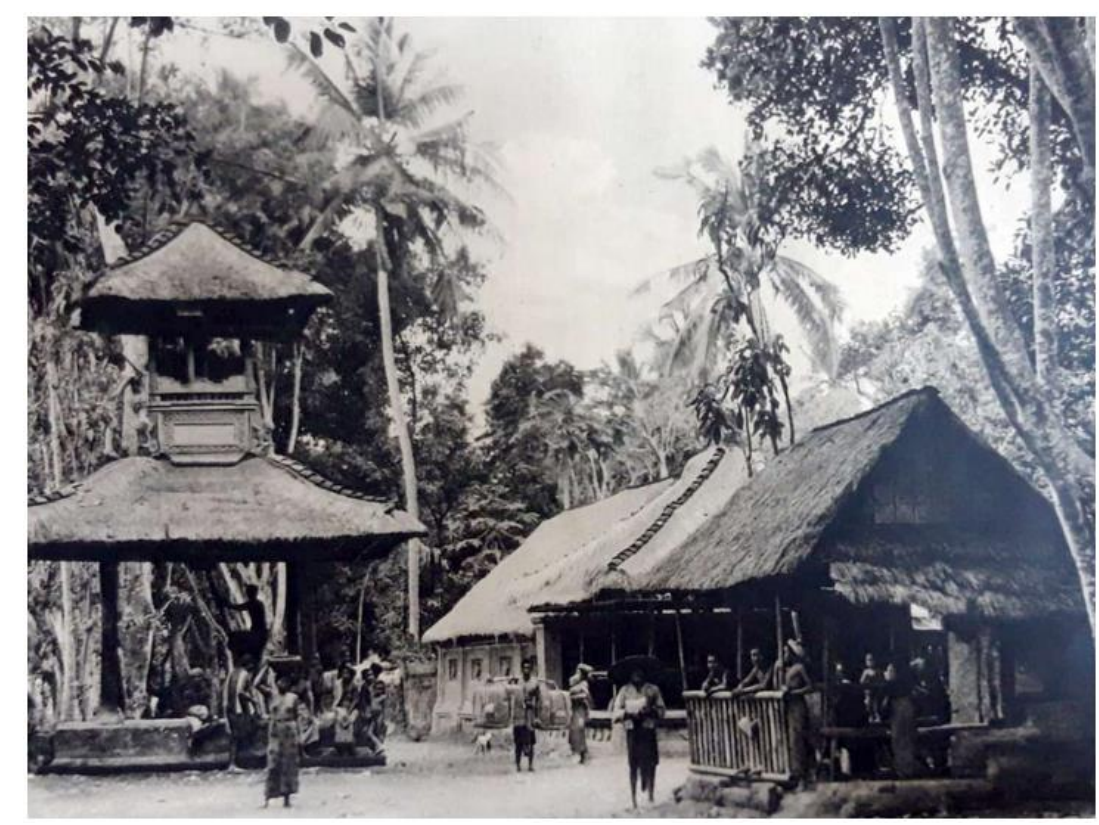

Figure 1. Architecture and spatial planning are inseparable parts of nature Source: Kersten, 1947 
Because it is constructed by local people in accordance with geographical conditions and local beliefs and ways of life, traditional settlements are physically and culturally compatible with nature and the human inhabitants. The application of cosmology creates an emotional connection between humans and the place where they live. This emotional connection forms the identity of the settlement.

The stability of this identity is guaranteed by the process of transmitting local knowledge from one generation to the next. In the process of transmission, modification and innovation occur in accordance with the development of traditional society (Oliver, 2007). The process of transmitting Balinese architectural knowledge was assisted through the writing of these sciences on the lontar Hasta Kosala Kosali and Hasta Bhumi.

\subsection{Colonialism: Early Meetings of Balinese and Western Architecture}

Identity stability is challenged when cosmological knowledge is challenged by new sciences that do not originate from understanding local nature. In addition, the management of residential areas is no longer in the hands of local communities, but in the hands of the formal-administrative government. The influx of outside investment also influences and dictates the creation of space. The initial challenge to identity stability came when Bali was conquered and managed by the Dutch Colonial Government. Before conquering Bali, the Dutch multinational company, the VOC, exploited the natural resources of the Indonesian archipelago. The bankruptcy of the VOC forced the Colonial Government to invite international investors to open businesses in the colonies. Together with investors, the first non-traditional architects came to the Dutch East Indies.

The conquest of Bali began from Buleleng in 1849. Buleleng was a strategic area because it had ports connected with islands in the western and eastern regions of the Dutch East Indies. In addition to serving the distribution of goods, the port is also an entry point for new knowledge flows. Next Badung and Klungkung surrendered respectively in 1906 and 1908. Since then, the role of the kings began to be reduced and a new system of government was introduced. The market in the city center is connected directly to the port to facilitate the distribution of goods. Community organizations are organized into structures based on ethnicity. These political, economic and social changes have resulted in an overhaul of the physical form of the city center. Central government and economic center are separated. Likewise, settlements of different ethnic populations are placed in different locations. Each group occupies a different area so that European settlement areas emerge with the best facilities, Chinatown and Arab clusters near the market, native environment which is spread outside the downtown area. This new city structure corrects traditional cosmology based on the principles of locality and culture.

To accommodate new activities, many non-traditional buildings which are founded with the main characteristic of thick walls function as bearers of the roof which are covered with white paint. Most of the material is imported from Java and even Europe including clay tile. All development matters are left to the Department of Public Works (BOW) while the government only applies safety and comfort standards. This denial of local knowledge, construction, and material makes European government areas and settlements contrast with the indigenous environment of local communities that are still managed and led by traditional communities. In addition, ethnic Chinese and Arab communities apply their respective cosmologies. As a result, in the colonial period cities in Bali were transformed into heterogeneous cities.

\subsection{Arsitektur Bali di Masa Politik Etis}

The currents of southern Bali's more rapid modernization began with the connection of the northern and southern regions of the island by roads built in the 1920s (Wijaya, 1984) This makes it easy for the government to take crops and bring them to the port and, conversely, bring modern goods to be marketed in the local market. Ports and markets that distribute goods from outside the region become the center of the economy while encouraging the modernization of Bali.

The exploitative patterns of colonialism, one of which was aimed at the pattern of the conquest of Bali which resulted in many victims, was criticized in the Netherlands (Vickers, 2012). This forced the Colonial Government to adopt a new policy that put the local people and culture in a better position. In Bali what is referred to as Baliseering is implemented in an effort to maintain and develop Balinese-based culture (Picard, 1997). Supported by port infrastructure in Buleleng and roads, the Colonial Government introduced tourism to place Bali and its people as subjects.

Because government buildings were carried out by the Department of Public Works, the initial tourism accommodation buildings were not far from the modern style buildings of the time. The guesthouse was built in Gitgit, Kintamani and in other areas including Klungkung to serve tourism. In Denpasar a hotel was built by the shipping company KPM. The design and workmanship was 
carried out by the firm Algemeen Ingenieurs- en Architectenbureau (AIA) which was founded by F.J.L. Ghijsels. This building, perhaps, was the first to use professional architects in Bali. The architectural design that is applied does not take references from local cosmology but emphasizes functionality.
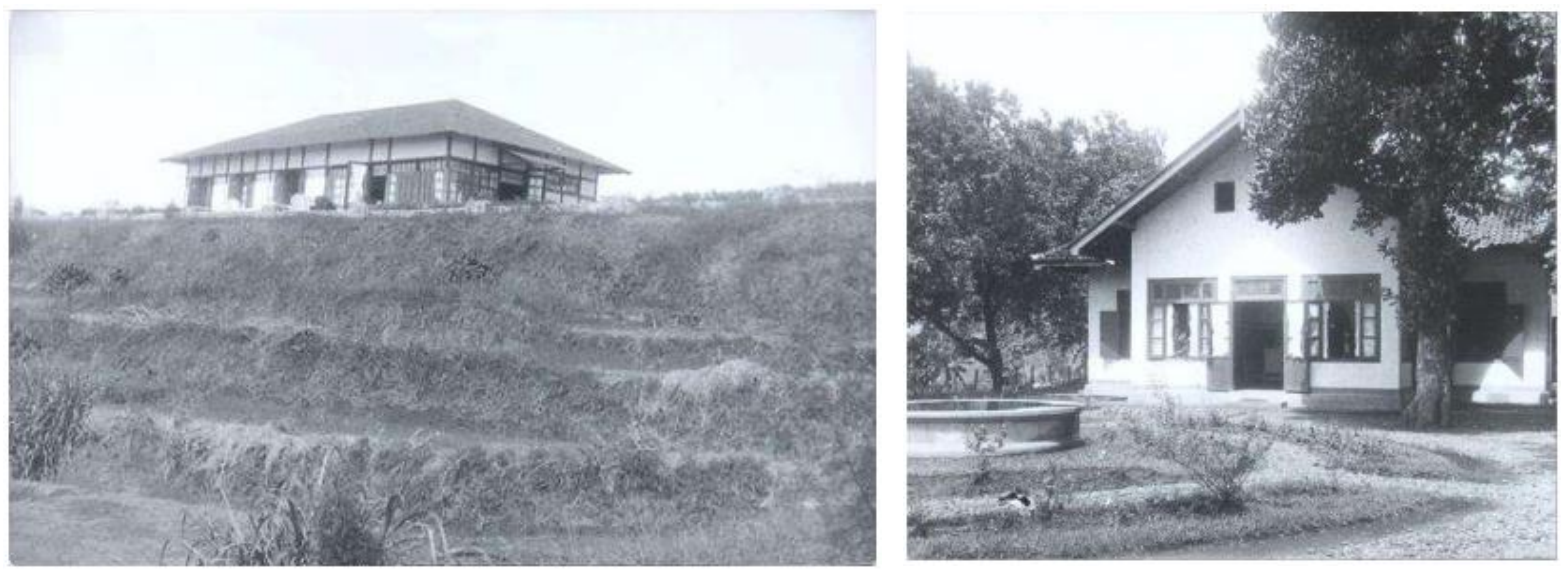

Figure 2. Two pesanggrahan buildings, in Kintamani and Gitgit, were built by the Colonial Government.

Picture: Troopenmuseum, Royal Tropical Institute.

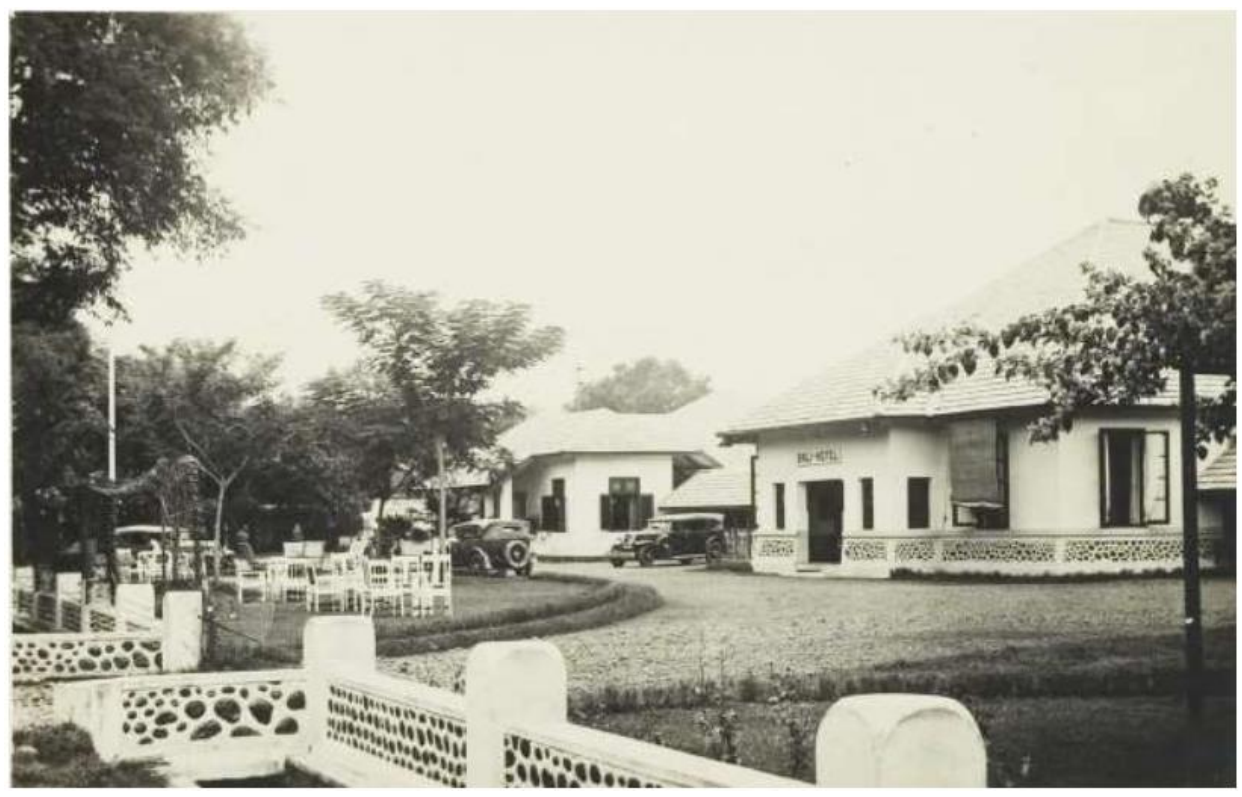

Figure 3. Bali Hotel in 1920 has non-traditional architecture.

Source: Leiden University Library, KITLV Collection.

In addition to the KPM company, Bali tourism is also desired by local leaders namely the king of Ubud who initially only wanted to get along and become part of the international community. For this purpose, many foreigners were invited to his castle including Walter Spies in 1928. Spies' interest in Balinese culture brought him to mingle with local residents and artists. With the local knowledge he mastered, Spies was one of the earliest critics of modern buildings in Bali (Stowel, 2012). He made scathing comments on almost all buildings of the Colonial Government. For him, these buildings are not suitable to be built in Bali. As a comparison, he built his house with a local architectural approach on a grant land from Ubud King. 

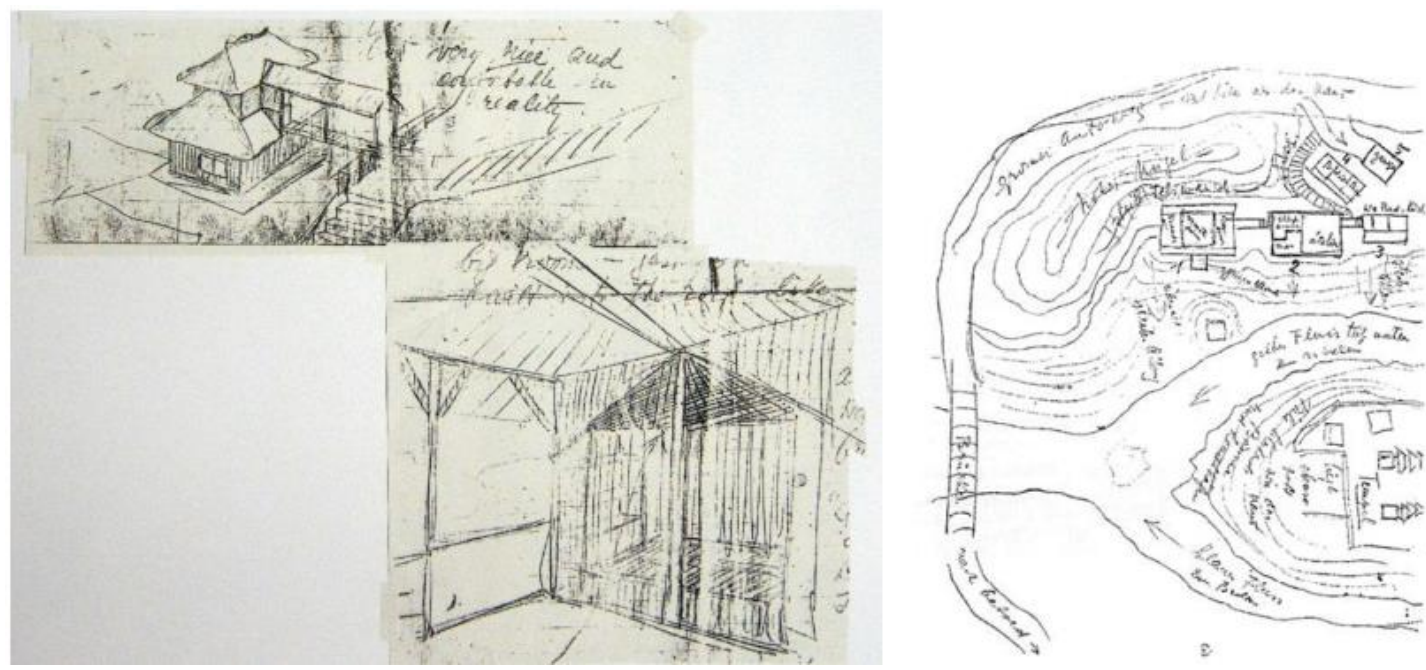

Figure 4. Sketches of Walter Spies' house on the river bank in Ubud Source: (Stowel, 2012)

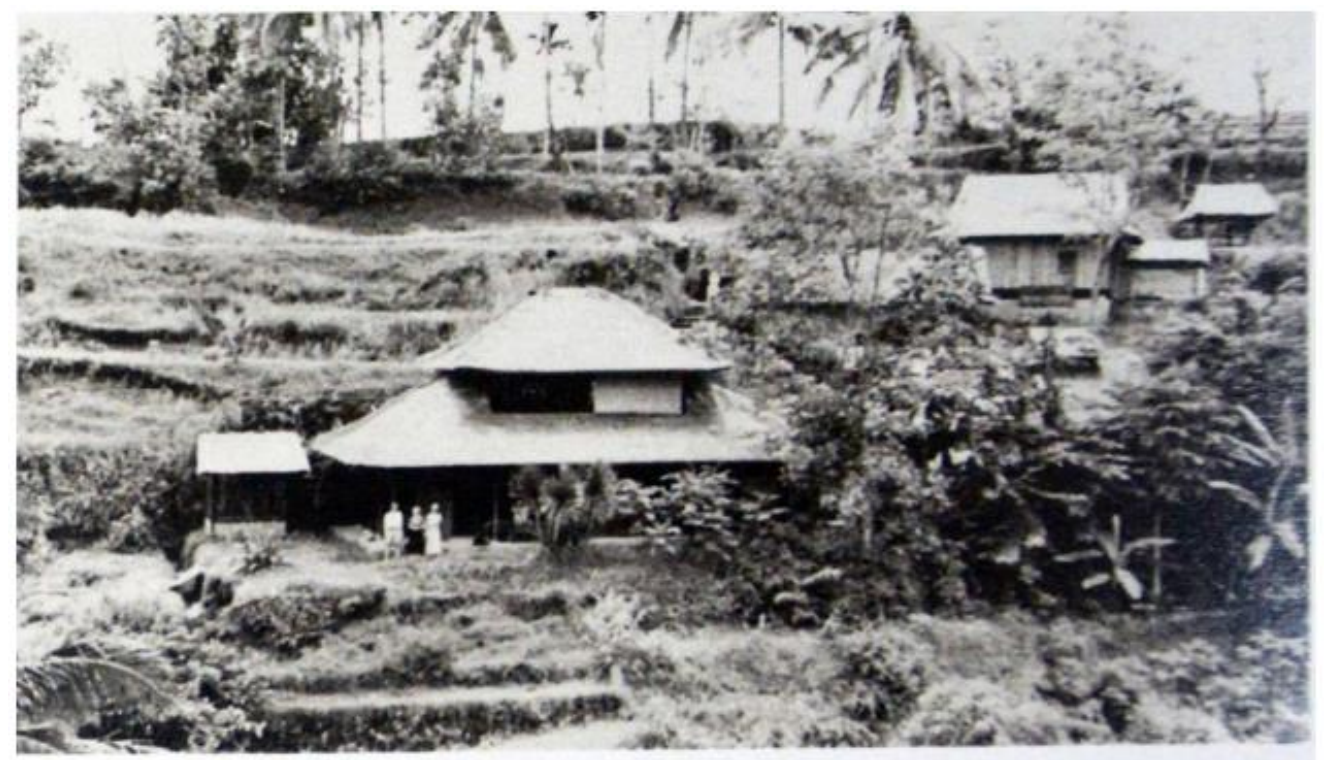

Figure 5. Walter Spies's house with an coarse grass roof and frame structure resembling a wantilan building.

Source: (Stowel, 2012)

In contrast to government employees who are reluctant to mingle with local people, Spies actually drowns himself as part of the local community. Perhaps this is where he gained knowledge of traditional architecture and put it into his home architecture. This building is a clear opponent of government buildings that use brick walls bearing the roof, painted white, tile roofs. The pavilion is a place to stay for Spies guests and early tourists, the forerunner of a boutique hotel that has recently become a trend.

Long before Spies came to Bali, architect P.A.J. Moojen, on orders from the Kingdom of the Netherlands, conducted a survey of buildings in Bali after the 1917 earthquake. The results of his study are summarized in the book Kunst op Bali (Moojen, 1926). Unfortunately Moojen did not have the opportunity to design and build in Bali. The opportunity to build actually came when the Colonial Government assigned him as an architect for the pavilion of the Dutch East Indies at the International Colonial Exhibition in Paris in 1931. Together with Sweedijk, his colleague who was also an architect, Moojen designed the pavilion with the hybrid architecture of BaliBatak. This spectacular pavilion received wide appreciation while attracting even more people to come to Bali. 
Awareness of the importance of local culture then spread to government employees where in the early 1930s began to build a Balinese museum in the center of Denpasar City. The museum was pioneered since 1910 and the decision to build with a traditional approach comes from discussions with Spies and an architect-anthropologist from Germany who were doing research in Bali. The limitations of traditional architectural knowledge are overcome by working with local undagi. Two undagi originals from Denpasar, I Gusti Ketut Rai and I Gusti Ketut Gede Kandel, were directly involved in the construction of this museum. The Bali Museum was the first to be built by the government with a local style and involving local workers. Among the local people, this museum is popularly known as Pura Kantor, referring to its temple-like shape and shelter function, in addition to the museum, administrative activities.

Utilization of local architectural images is also applied to other museums in Ubud where a group of artists who gather themselves in the Pitha Maha association initiates a museum. The aim is to protect the works of the best local artists from the harmful trade in art (Couteau, 1999). The design, which was done by the painter Rudolf Bonnet, was probably inspired by the shape of a continuous saddle roof that can be found in the Old Bali Village area, Tenganan

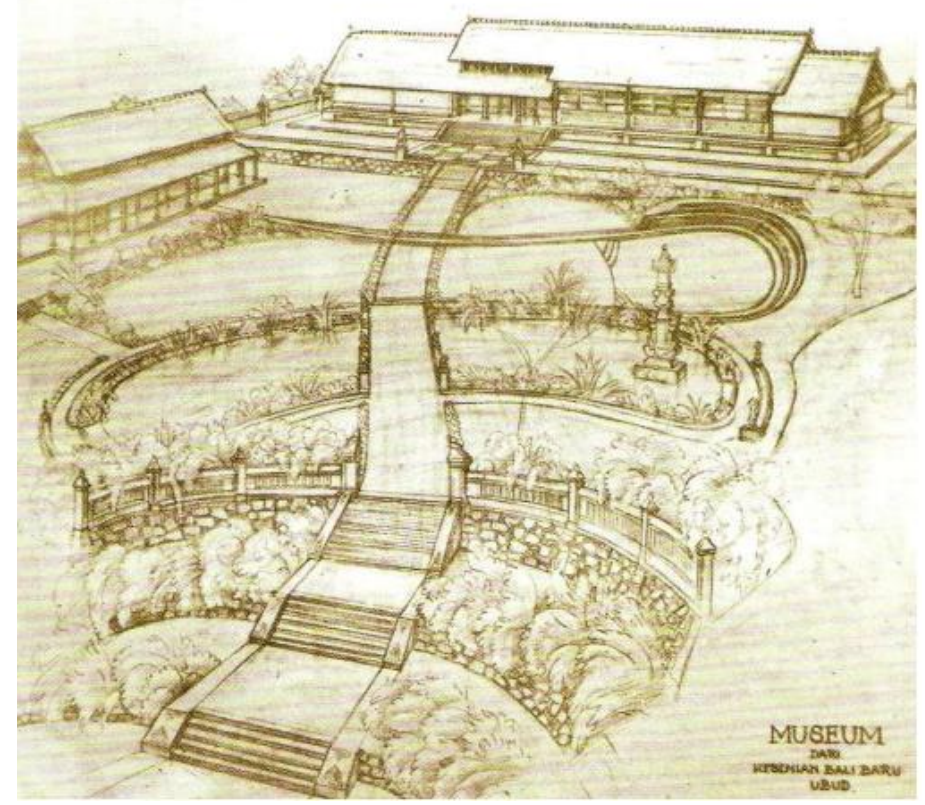

Figure 6. Image of the Museum Building plan of the New Bali Arts which later became Museum Ratna Wartha Puri Lukisan in Ubud.

Picture: (Sarojini, 2010)

The colonial period is a time when traditional architecture is transformed into a container of non-traditional activities. no longer limited as a residence and place of worship, Balinese architecture at that time accommodated the functions of lodging, offices and museums. This happened after the awareness of the importance of maintaining Balinese culture which grew among non-Balinese people.

\subsection{Modernization and Architectural Nationalism}

The Dutch Colonial Government did not have enough time to continue the successful application of local architecture in the buildings he made. About ten years after the founding of the Bali Museum, Japanese troops came to replace the leadership in Bali. The Japanese occupation lasted for a relatively short period of time, approximately 3.5 years. The Colonial Government had come back after the occupation but in 1950, Bali joined the Republic of Indonesia which was proclaimed by Sukarno. Under the new government, architecture and spatial planning in Bali again underwent a transformation.

Sukarno was well aware of the diversity of elements that made up the Republic of Indonesia. Indonesia's first president made use of urban architecture and design to shape the vision of a sovereign, developed, and free state of colonialism (Kusno, 2000). Modern principles are applied to describe progress while uniting cultural diversity. Steel and concrete, a marker of modern 
architecture at that time, became the norm in every facility that was built. However, in order to escape from colonialism, Sukarno also used local symbols such as the modified Lingga Yoni. At the local level, he encouraged the people to maintain and promote culture without having to imitate the legacy of the Colonial Government.

The current of optimism in welcoming the glorious modern future aspired by Sukarno spread to architecture at the local level. The 'progress' vision is represented by the community by adopting non-traditional forms and materials to be applied to traditional buildings. This is in contrast to the colonial period which made use of traditional architecture to accommodate modern functions. the expansion of modern styles in the 1950s to the 1970s, assisted by craftsmen who had experience building colonial government buildings.

Modern post-colonial architecture is also rife in many other cities in Indonesia as confidence develops to become modern. Politically, architectural identity is used to build a sense of unity, overcome differences and foster optimism for the people of Indonesia for a more glorious future.
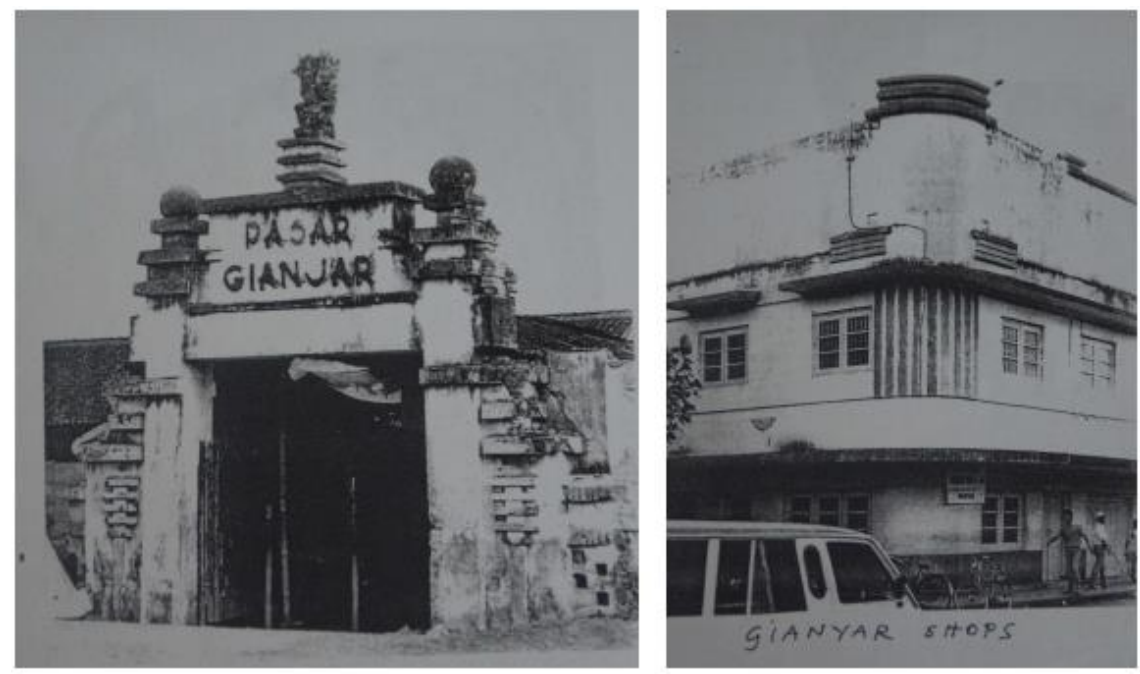

Figure 7. The building of modern market gate and shops in Gianyar Picture: (Wijaya, 1984)

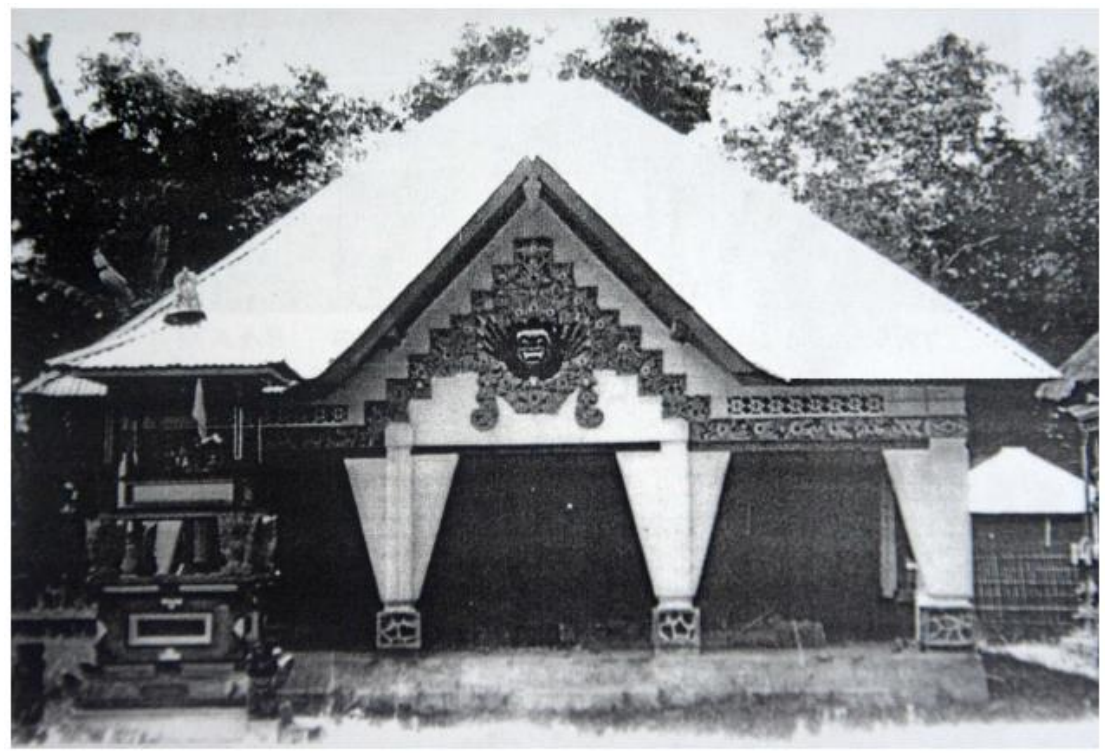

Figure 8. Wantilan Pura in Katung Village Picture: (Wijaya, 1984) 


\subsection{New Age Tourism and Emergence of Architecture 'Bali Style'}

The motives for developing tourism in the early independence era were aimed at building an identity, in contrast to the economic motives of the colonial government. Bali, which at the beginning of the 20th century had received international exposure, was used by Sukarno as one of the display cases to show the progress and superiority of Indonesian culture. A very large new hotel of its time, the Bali Beach Hotel, was founded in the Sanur Region in 1963. Its architecture was adapted to Sukarno's modern vision.

Before the Bali Beach Hotel was built, the Sanur area was inhabited by a number of smaller scale lodgings. The presence of a new hotel with a shape and size that is so massive invite attention and criticism. Wija Waworuntu, an oriental interior collector and businessman, and Donald Friend, an Australian-born painter, were disturbed by the modern architecture of the Bali Beach Hotel. As an alternative, they renovated the Tandjung Sari small inn owned by the Wija family in a different style. Material, ornament and local construction are applied to create an area that will welcome this guest. The adoption of this tradition has succeeded in becoming an iconic lobby.

In their hands, a vision to develop Balinese tourism by utilizing local architectural knowledge was the focus. Friend and Wija opened up new land and invited Australian architect Peter Muller to come to Bali. Its main mission is to build comprehensive tourism facilities that fully utilize the knowledge of traditional Balinese architecture. Detailed studies of Balinese architecture were carried out and the results were translated into the Matahari Hotel proposal in 1970 (Robson, 2002). The design represents a traditional village complete with a banyan tree and commercial facilities similar to a village market. Muller made a little compromise by turning the whole complex, not purely following the mountain-sea axis, so that all rooms had a beach view. The lobby building adopts the wantilan structure while the hotel rooms are equivalent to residential houses with angkul-angkul as the entrance.

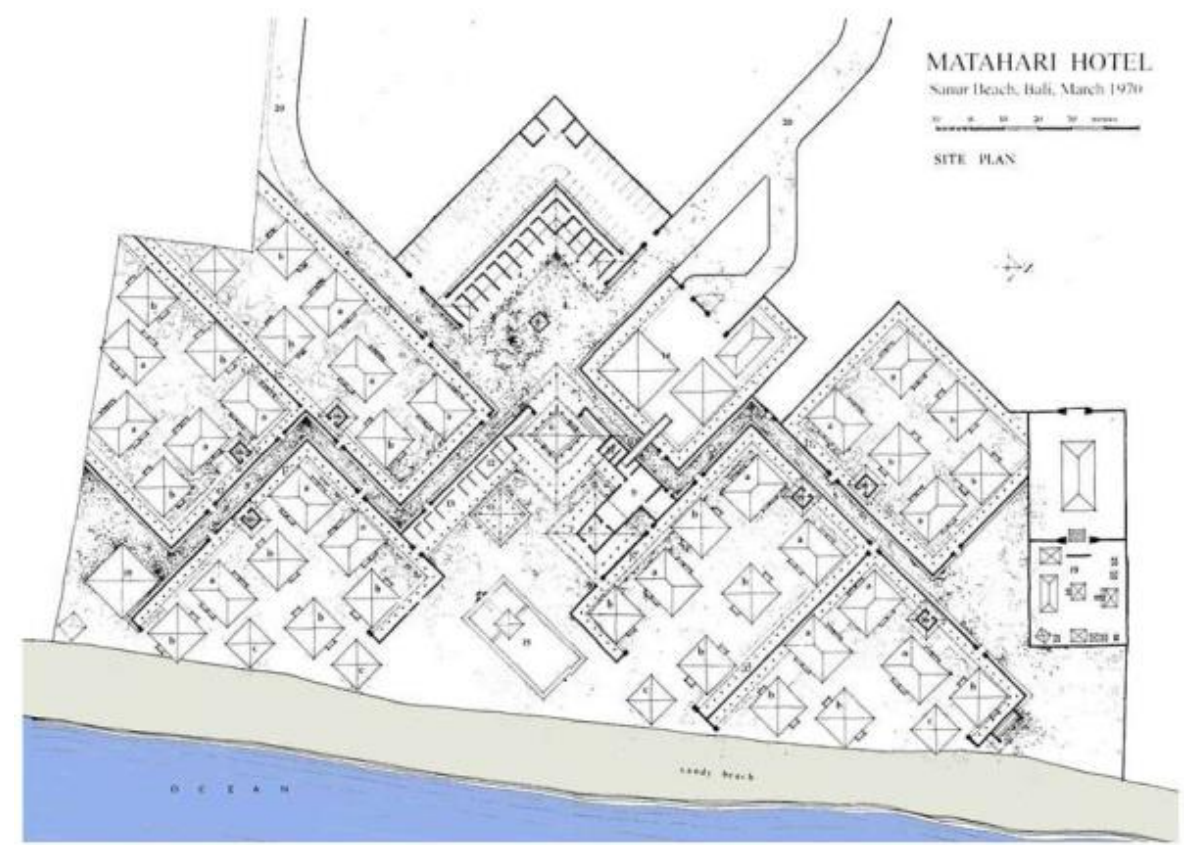

Figure 9. Layout Matahari Hotel (proposal) by Peter Muller Source: https://pmi.viewbook.com/album/matahari.html

Not only for Wija and Bawa, the design contained in the Matahari Hotel proposal invites appreciation from a wide audience in the tourism business. Unfortunately the popularity of Peter Muller's design failed to help this project to obtain funding. Various problems, especially the world economic conditions which were lethargic at that time, might be the reason. 


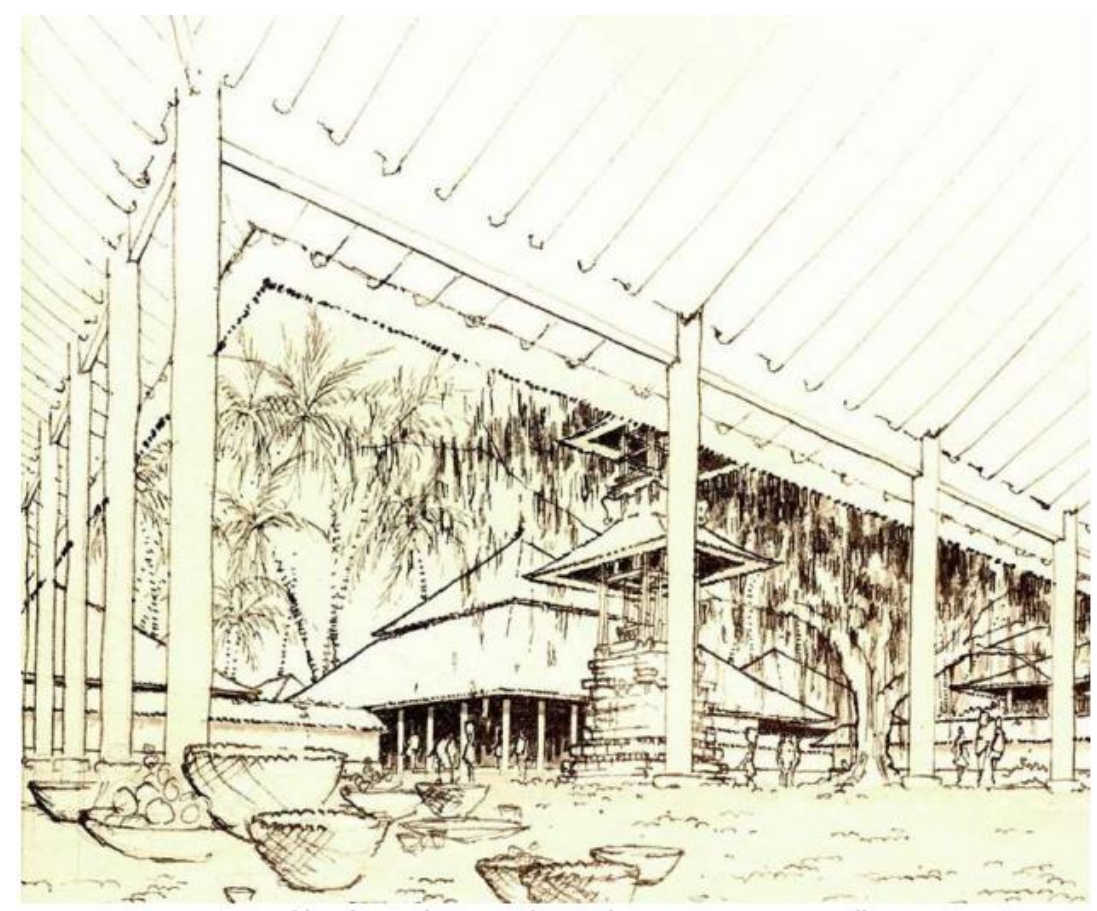

Figure 10. Central 'desa' Matahari Beach Hotel Peter Muller's design Source: https://pmi.viewbook.com/album/matahari.html

The Matahari Hotel Proposal, in terms of design, proves that traditional knowledge has vast possibilities to be developed into non-traditional facilities. This is inherent in the minds of many people, especially investors, so that Peter Muller enjoys his popularity. This 'success' led to the next several assignments in Bali, with the traditional architectural adoption approach, including: Kayu Aya (1973), the Oberoi (1977), to the hotels of the Aman group.

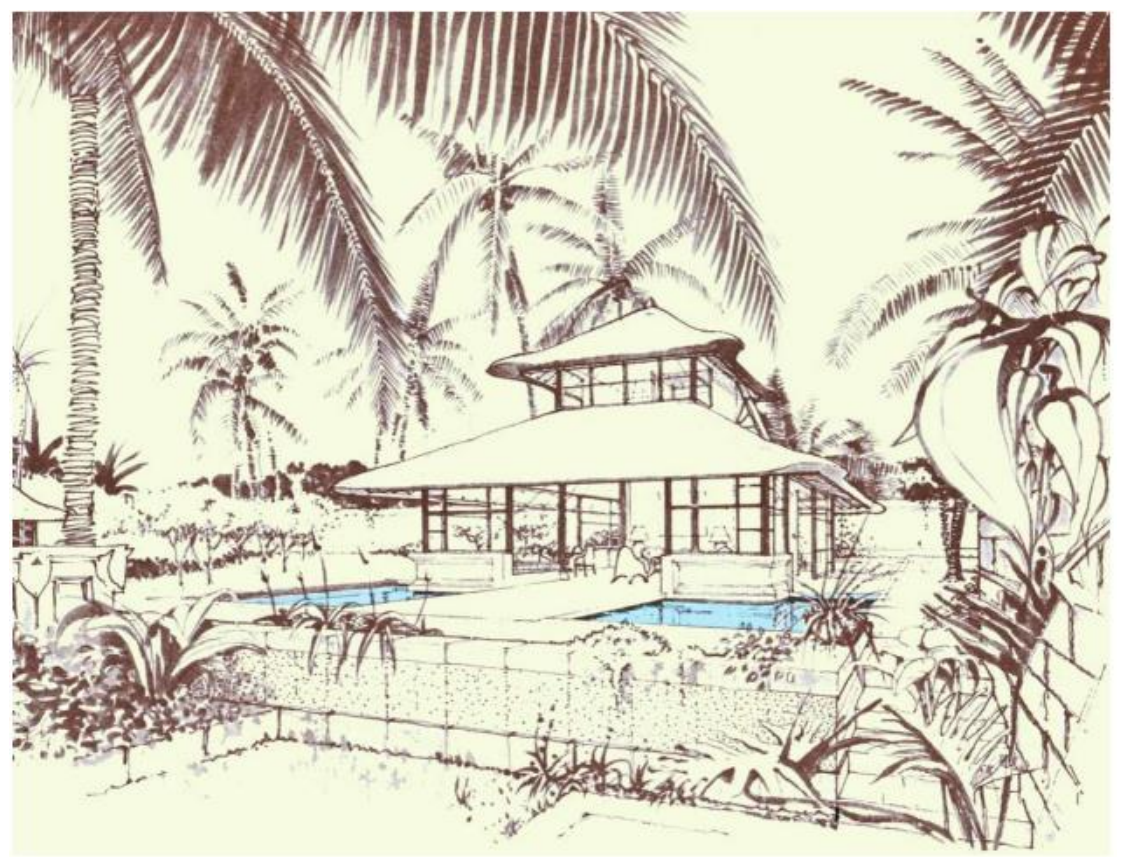

Figure 11. Design of a pavilion at Amandari Hotel by Peter Muller Source: https://pmi.viewbook.com/album/matahari.html

The Matahari Hotel Proposal proves that Balinese architectural identity can be capitalized to obtain economic benefits. The failure to collaborate with Muller brought Wija and Friend to the next collaboration with Geoffrey Bawa. Bawa is more interested in the architecture of individual buildings 
compared to the arrangement of a traditional village. This can be seen in the design proposals produced, in the form of the Batu Jimbar complex which emphasizes the architectural quality of each villa. At almost the same time, on the land where Matahari Hotel was originally going to be built, the Hyatt Hotel was built by a Hong Kong corporation. Wija and Friend provided input so that the elements of traditional architecture were applied to designs that initially seemed entirely modern.

Starting with the Matahari Hotel proposal, the adoption of traditional Balinese architecture into tourist accommodation facilities seemed to be the architectural norm in the late 1960s to the late 1980s. This design approach creates what is referred to as 'Bali Style' (Helmi \& Walker, 1995). This is proof that the local architectural identity with its romanticism has an economically privileged position.

\subsection{Balinese-modern Office Architecture}

The government is worried that the massive development of tourism at that time, besides being economically profitable, could cause damage to the natural and artificial environment in Bali. Sponsored by the central government, a massive tourism development study was conducted by the SCETO (Societe Centrale pour I'Aequipment Touristique Ouetre-Mer). In its study published in 1971, SCETO recommended a number of important things with the aim of avoiding Bali from the social, natural and cultural damage that might result from tourism development. One of them is formulating a general tourism development plan (masterplan) that focuses on efforts to maintain cultural and natural excellence and prefers a strategy of developing quality tourism or limited but quality tourism. In line with these efforts, as well as to guide the construction of new facilities in Bali, in 1974 the government issued three sets of local regulations, Perda no. 2, 3, and 4, to regulate physical development in Bali.

In addition to buildings for tourism, the early independence period was also filled with the rush of government office projects in Bali. These projects are generally carried out by Indonesian and also local Balinese architects. In Jakarta, the early generation graduates of the Bandung Institute of Technology's architectural program took on many roles. The dropout from these government projects enlivened the development of Indonesia's non-traditional architecture, one of which was Robi Sularto and his colleagues who were members of the Atelier 6 firm.

In accordance with SCETO's recommendation, the government built a hotel in Nusa Dua that was designed by the office of PT. Atelier 6 . In layout, the hotel takes the traditional philosophy of trimandala but is manifested in the form of a multi-storey modern building. Building materials and modern construction systems such as concrete, steel and glass continue to be applied. Traditional ornamental ornaments in the form of carvings as well as the bale kulkul and the Candi bentar 'only' are complementary. The result, a hotel with local ambiance without taking the full form of traditional Balinese buildings. The hotel is considered successful in negotiating between modern, in accordance with the vision of advanced Indonesia, and tradition, as a cornerstone of architecture. Since that time the central government recommended that all offices be built with regard to the culture of the local building. Unlike in pre-colonial times, architectural identity at this time no longer happened by chance but was designed to be able to be a representation of the nation.

In Bali, this 'designed' identity is transformed into government office buildings where Robi Sularto takes a lot of roles. Furthermore, local architects began to grow thanks to the opening of the department of architecture at Udayana University, where Robi was one of the initiators. One thing worth mentioning is Ida Bagus Tugur, an artist who has not received formal architecture education. His expertise in processing and transforming ideas into building forms led him to become one of the extraordinary lecturers at the Department of Architecture at Udayana University. Since the late 1960s he began to be heavily involved in physical development projects. His knowledge of puppet stories is a strong foundation in his architectural works (Putra, N, 2015). Tugur received many assignments from local governments in Bali both at the provincial and district levels to design offices. The idealism of wayang stories is forming the identity of architecture in the hands of Tugur. What is unique about office architecture is its focus on figure and ornament. We rarely encounter office architecture that uses cosmological considerations as an effort to create a micro climate in the room and disaster mitigation

Between the 1970s and 2000s, architectural identity in Bali was segmented into two: tourism architecture that sought to explore the values of traditional romanticism, and office architecture that sought to meet modernism. This segmentation was formed by two big capitalists, namely private and government investors. In most societies, architecture is still an 'expensive item' so its development does not have a major influence on the development of identity in general. 


\subsection{Future Balinese Architecture, Like What?}

In the 2000s to this day began to emerge individuals who financially have the ability to assign architects to design the house or residence. This enriches the treasury of architectural styles on the island of Bali. In addition, markets formed by private and government investors continue to be magnets. The flow of Balinese architectural identity is now shaped by these three forces, but each has specifications that make it possible to break into smaller branches.

We have seen that identity transformation is shaped by changes in social, political and economic values. Today, the people who inhabit this island have become heterogeneous socially, no longer just holders of Hindu-Balinese beliefs, so cosmological perceptions are very diverse. Traditional government no longer holds absolute control over its territory since there is a national government that can intervene in the creation of space at the local level. The influence of the central government can be very strong as happened at the beginning of independence. In addition, the economy has been transformed into lingua franca every activity of modern humans. This also applies in the field of architecture. Buildings that can make money become strong investment magnets. The transformation of social, political and economic values, aided by technological developments, took place so rapidly that architectural styles also changed rapidly. However, in the midst of these rapid changes, there are cultural components that remain as the backbone that can be used as a handle. The component is the geographical situation of the island of Bali and how it is translated so that humans are able to live in harmony with it.

Knowledge of the efforts of traditional societies to be in harmony with the workings of nature that shape this tradition is forgotten in the midst of the hustle and bustle of identity politics that prioritizes form and ornament. Efforts to mimic form will never be able to give value to tradition, because it assumes architecture has been frozen in the past. Such a view can result in architecture becoming a rigid artifact. Or perhaps this happens because we have failed to translate the workings of nature that successfully shaped the traditions of the past? Or fail to find the universal values of the tradition that consider it threatened by other values? We are afraid that the translation that has been done by the ancestors will fade by the translation made by the 'outside'? This kind of fear is actually dangerous because it can lead us to the nature of excessive chauvinism, viewing traditional architecture as dogma.

Then what is our biggest challenge today?

For me, the biggest challenge is finding the universal value of our tradition that stems from efforts to live in harmony with the character of the island of Bali and to continue this understanding into the workings of the buildings we make today with all the consequences. The consequences that may arise are a matter of correcting architectural education patterns in order to be able to continue, not merely perpetuate, the inheritance of traditional knowledge; planting more trees that can be used as building materials, protecting water sources so that agrarian culture is not lost, and disaster mitigation.

\section{Bibliography}

Couteau, J. (1999). Museum Puri Lukisan ubud. Ubud: Yayasan Ratna Wartha.

Helmi, R., \& Walker, B. (1995). Bali Style. London: Thames and Hudson.

Kersten, J. (1947). Bali. Eindhoven: Uitgeversmaatschappij De Pelgrim NV.

Kusno, A. (2000). Behind the Postcolonial: Architecture, Urban Space and Political Cultures in Indonesia. New York: Routledge.

Moojen, P. (1926). Kunst op Bali: inleidende studie tot de bouwkunst. Bandung: Adi Poestaka.

Nordholt, H. S. (2011). Indonesia in the 1950s Nation, modernity, and the post-colonial state. Bijdragen tot de Taal-, Land- en Volkenkunde, 386-404

Oliver, P. (2007). Dwellings: the Vernacular House Worldwide (New editio). London: Phaidon Press Ltd.

Pearson, C. (1998). Indonesia Design and Culture. New York: Monacelli Press

Picard, M. (1997). Bali: Cultural Tourism and Touristic Culture. Singapore: Archipelago Press.

Putra, N, G. (2015). ida bagus tugur dan robisularto arsitektur bali pasca hasta kosala kosali dan hasta bhumi. Retrieved from https://gedemahaputra.wordpress.com/2015/03/09/ida-bagustugur-dan-robisularto-arsitektur-bali-pasca-hasta-kosala-kosali-dan-hasta-bhumi/

Robson, D. (2002). Geoffrey Bawa: The Complete Works. London: Thames and Hudson.

Stowel, J. (2012). Walter Spies: a Life in Art. Jakarta: Afterhours.

Vickers, A. (2012). Bali: A Paradise Created. Singapore: Tuttle Publishing.

Wijaya, M. (1984). Balinese Architecture: Towards an Encyclopaedia. Denpasar: Wijaya Words. 